\title{
The effect of business characteristics on tax compliance costs
}

\author{
Popi Fauziatia $^{a^{*}}$ and Aza Azlina Md Kassim ${ }^{b}$
}

${ }^{a}$ Department of Accounting, Faculty of Economic, Bung Hatta University, Indonesia

${ }^{a, b}$ Faculty of Business and Accountancy, Universiti Selangor, Malaysia

CH R O N I C LE A B S T RACT

\section{Article history:}

Received: November 26, 2017

Received in revised format:

March 31, 2018

Accepted: April 4, 2018

Available online:

April 5, 2018

Keywords:

Tax compliance costs

Age

Size

Sector

Risk management

\begin{abstract}
Compliance fee is the cost incurred by the taxpayers in fulfilling the taxation requirements imposed on the taxpayers by the law and the authority of the country. The company expects to incur the minimum tax costs associated with fulfilling its tax obligations. Research on the influence of business characteristics to tax compliance cost is still scanty. This research examined the effect of business characteristics (age, size, sector and risk management) on tax compliance costs. The research design adopted in this study is survey design. The questionnaires were distributed to the members of Department of Cooperatives and Micro Small-Medium Enterprises in Padang City. The non-probability sampling was used as the sampling method and 92 respondents participated in this research. The data obtained were analyzed using Statistical Package for Social Sciences (SPSS). The research findings indicate that age, size and sector have no effect on tax compliance costs while risk management has an effect on tax compliance costs.
\end{abstract}

\section{Introduction}

Tax is the domestic revenue which is the largest source of state financing in administering the government. Development will not be achieved maximally without adequate financing support, for that in this sector domestic acceptance, especially the tax sector is needed in order to achieve the state goal for the welfare of society. According to the Indonesian Tax Law no. 28/2007, tax refers to the revenue that is collected by the government to provide services and to support the development. Specifically, government utilizes tax proceeds to fund development programs, such as supplying public goods, defraying infra-structure cost, and creating a competitive trade and business regulation to assure social and economic maintenance. Thus, the role of tax in supporting the economy of a country is important.

One way to optimize collection is by applying Self Assessment System (SAS). The application of SAS is to increase collection rates, minimize tax collection costs and to encourage voluntary compliance (Kasipillai, 2007; Garg, 2017). However, the new application of SAS involves shifting substantial responsibilities to taxpayers in terms of calculating accurate tax amounts and making payments on a calculated basis. In addition, the taxpayer must also be responsible for maintaining the correct records 
and keeping records in safe custody, resulting in increased taxpayer compliance costs. According to Smulders and Stiglingh (2008), tax compliance cost is divided into 4 groups: (1) the amount of time spent by business owners, managers, staff, and others on understanding and applying the rules; (2) record-keeping costs, (3) the payments for the expertise of professional advisors such as consultants, lawyers, and accountants, and 4) incidental costs such as postage, telephone, and travel cost whereby these cost are incurred in communicating with advisors or the tax authorities.

\section{Literature review}

\subsection{Tax compliance costs (TCC)}

The empirical research on TCC is scarce, there have been a number of investigations in certain countries and regions around the world, among which are Australia (Tran-Nam \& Glover, 2002), US (Slemrod \& Venkatesh, 2002), Canada (Clemens, 2008), the UK (Hansford et al., 2003), Belgium (Schoonjans et al., 2011), Malaysia (Ibrahim \& Pope, 2011; Sapiei \& Abdullah, 2014), South Africa (Smulders et al., 2017) and Indonesia (Savitri, 2016). A problem with international comparisons, however, is that there is no common definition of compliance cost and no accepted methodology to obtain empirical assessments (Chittenden et al., 2003; Das, 2018). While cross-country comparisons are thus tedious to perform and has to be treated with care, there nonetheless appears to be consensus that TCC are significant (Ahmadi \& Bouri, 2017).

\subsection{Business age}

The more established businesses incur, the higher internal tax comparison fees compared with the younger businesses. This is due to the higher level of tax complexity compared with the less younger businesses (Eichfelder \& Schorn, 2008). There is a simple link between the age of a business and internal tax. New businesses tend to generate small or low turnover with simple business structures. As businesses become more successful over time and their turnover grow, owners tend to favour more complex business structures, particularly incorporation, to minimise risk and tax. This can increase both tax and non-tax compliance costs (McGregor-Lowndes \& Ryan, 2009). Hence, the study assumes that business age influences on tax compliance costs.

\subsection{Business size}

Coolidge et al. (2009) found that as the size of the business increases, the absolute external tax compliance costs also increase too. Three measures of business size can be used - turnover, number of employees and gross asset value. As the information associated with only two of these measures became available, only turnover and the number of employees could be considered. To learn which one of these variables maintains a stronger impact on tax compliance hours/ costs, both variables were included in the analysis. The number of small (medium and big) businesses is disproportionately low (high). The same is true for some of the sectors such as the construction. This is because of the fact that the size classes containing bigger businesses and some sectors could be deliberately overweighted to reach a sufficient number of businesses for each sector and size cell. That was especially necessary to derive an aggregate cost estimate (Eichfelder \& Schorn, 2012).

Several studies have reported a negative relationship between company size and compliance expenses relative to turnover (Slemrod \& Venkatesh, 2002; Smulders et al., 2017; Hanefah et al., 2002). In a comprehensive review of administrative and compliance costs of goods and services taxes (GSTs), Cnossen (1994) reported that the relative compliance costs associated with GSTs predominantly encumber SMEs. The reason that small businesses bear higher relative compliance costs can partly be described because compliance costs can be considered fixed up to a certain extent. Thus, large firms 
may enjoy economies of scale in their compliance expenses. Therefore, the study assumes that business size influences tax compliance costs.

\subsection{Business sector}

The sector in which a small business operates is not a significant determinant of external tax compliance costs (Verwaal \& Cnossen, 2002; Reekmans \& Simoens, 2010; Slemrod \& Venkatesh, 2002). However, Hansford and Hasseldine (2012) found that some sectors such as manufacturing, services and dealing in the goods sectors had lower value-added tax (VAT) compliance expenses than others. Eichfelder and Schorn (2008) also found that the service sectors maintained higher tax compliance costs (including the time burden) than the building sector. The results of the current study found that the transport, postal and warehousing sectors, followed by the mining and electricity, gas, water supply and waste removal sectors, were the sectors which paid the most for outsourcing their tax functions in this study. Hence, the study assumes that sector influences tax compliance costs.

\subsection{Risk Management}

According to Labodová (2004) risk is a combination of probability that some (dangerous) events will occur and the consequences of it if it actually happens. From this definition two variables are identified: the frequency of the occurrence (probability) of the risk event, that is to say the number of times that it happens during a set period of time; and the magnitude of the event, which is the set of consequences that can result if the event occurs. Thus, risk is the chance of something or an event happening that would have effect upon set goals that is unexpected and unforeseen. Put differently risk is the possibility of deviation from a planned outcome or goal. According to Coso (2004) the risking events can be classified into two- external and internal factors. Economic, environmental, political, social and technological factors can be classified as external. Moreover infrastructure, human, process and technology can be categorized as internal factors.

According to Majengo (Majengo, 2014) risks are inherent in an organization tax system. Risk can be classified into valuation, reputation and operation risk. Valuations risks are referred to the risks that the tax amount disclosed in financial statements are wrong. This may include both corporate taxes, differed taxes and transaction taxes as VAT and other levies. Meanwhile, reputation risk refers to the failure to pay taxes that may have a negative impact on the organization. Normally it appears after a revenue authority audit process that may disclose additional taxes that are well above its cash flow ability. Operation risks are the taxes that are outside the scope of the tax department but may curtail business performance, e.g. payroll taxes, VAT and information reporting. Hence, the study assumes that risk management influences tax compliance costs.

\section{The proposed method}

\subsection{Hyphotheses}

H1 : Business age influences on tax compliance costs.

H2 : Business sector influences on tax compliance costs.

H3 : Business size influences on tax compliance costs.

H4 : Risk management influences on tax compliance costs.

\subsection{Methodology}


The sample in this research is small medium enterprise (SME) registered in Department of Cooperatives and Micro Small-Medium Enterprises in Padang City. The data collection for this study utilized a researcher-administered questionnaire survey method. The questionnaire was sent out to 100 small business taxpayers with a response rate of $95 \%$ ( 95 respondents). The instruments are development of questionnaires adopted from in Likert scale with five options including $1=$ Strongly agree, $2=$ Agree, $3=$ Uncertain, $4=$ Diagree and $5=$ Strongly disagree. The definitions and measurements of each variable are described as follows:

$\mathrm{X}_{\text {age: }}$ The age of the business. The age categories of the businesses was defined in the regression model as: 1 if the business had been in operation for five years or less and 2 (the reference category) if the business had been operating for more than five years.

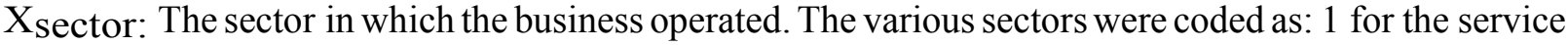
sector; 2 for the retail sector; 3 for the manufacturing sector.

$\mathrm{X}_{\text {Size: }}$ The total assets of the companies. In our survey, it was 1 if total assets $<50$ milion rupiahs; 2 if total assets $>50$ milion rupiah and $<500$ milion rupiahs; 3 if total assets $>500$ milion rupiah and $<10$ bilion rupiahs.

XRm: Risks that include valuation risk, reputation risk and operation risk.

TCC: Expenses incurred to calculate, pay and report taxes. These costs include the cost of using stationery, internet payment, software purchases and professional hiring costs such as accountant or tax consultants.

\section{Findings}

The questionnaires distributed were 100 copies and the researcher managed to get 95 copies of returned questionnaires. To verify the instrument of question, validity and reliability test were conducted. The results of validity and reliability tests are shown in Table 1.

Table 1

Reability and Validity

\begin{tabular}{lllll}
\hline Variables & $\begin{array}{l}\text { Cronbach's } \\
\text { Alpha }\end{array}$ & Kaiser-Meyer-Olkin & Factor loading & Decision \\
\hline $\begin{array}{l}\text { Tax compliance } \\
\text { costs }\end{array}$ & 0.707 & 0.734 & $0.474-0.854$ & Reliable and Valid \\
Risk Management & 0.606 & 0.636 & $0.483-0.687$ & Reliable and Valid \\
\hline
\end{tabular}

From Table 2, R-Square value of 0.067 means the influence of business characteristics to tax compliance costs of $6.7 \%$. This influence is very weak because it is below 0.50 .

Table 2

Model summary

Std. Error of the Esti-

\begin{tabular}{l|cccc} 
Model & $\mathrm{R}$ & R Square & Adjusted R Square & mate \\
\hline 1 & $.259^{\mathrm{a}}$ & .067 & .024 & 4.27252 \\
\hline
\end{tabular}

a. Predictors: (Constant), RM, Size, Sector, Age

Table 3 shows that that the age, sector and size do not influence on the tax compliance costs because the value of significance is bigger than $0.05(0.595 ; 0.464 ; 0.849)$. With regards to risk management, it 
indicates that it has an effect on tax compliance since the value of significance is smaller than 0.05 (0.021).

Table 3

The summary of Step-wise regression estimate

\begin{tabular}{|c|c|c|c|c|c|c|}
\hline \multirow[b]{2}{*}{ Model } & & \multicolumn{2}{|c|}{ Unstandardized Coefficients } & \multicolumn{2}{|c|}{ Standardized } & \multirow[b]{2}{*}{ Sig. } \\
\hline & & $\mathrm{B}$ & Std. Error & Beta & $\mathrm{t}$ & \\
\hline \multirow[t]{5}{*}{1} & (Constant) & 16.094 & 4.293 & & 3.749 & .000 \\
\hline & Age & .492 & .922 & .057 & .534 & .595 \\
\hline & Sector & .460 & .626 & .078 & .735 & .464 \\
\hline & Size & .591 & 3.090 & .020 & .191 & .849 \\
\hline & $\mathrm{RM}$ & .269 & .115 & .244 & 2.342 & .021 \\
\hline
\end{tabular}

a. Dependent Variable: TCC

\section{Conclusion}

The study has examined the influence of business characteristics on tax compliance costs. The result indicates that age, sector and business size had no effect on tax compliance cost. For business age and size, established businesses and the younger businesses do not require tax costs to meet their tax obligations. Business sectors included in the small medium enterprise do not calculate the cost of calculating, paying and reporting taxes. In relation to risk management, the study has found that risk management could influence on tax compliance cost. This finding is consistent with Majengo (2014) in which the company provides the cost to fullfill its tax obligations. With the fulfillment of obligations, the level of compliance and impact on corporate reputation in stakeholders to be good. This findings will provide important insights to services' policy makers, practitioners, academicians and other regulatory authorities in policy formulations.

\section{References}

Ahmadi, A \& Bouri, A. (2017). Board of directors' composition and performance in French CAC 40 listed firms. Accounting, 3(4), 245-256.

Chittenden, F., Kauser, S., \& Poutziouris, P. (2003). Tax regulation and small business in the USA, UK, Australia and New Zealand. International Small Business Journal, 21(1), 93-115.

Clemens, J. (Ed.). (2008). The Impact and Cost of Taxation in Canada: The Case for Flat Tax Reform. The Fraser Institute.

Coolidge, J., \& Ilic, D. (2009). Tax compliance perceptions and formalization of small businesses in South Africa.

Coso, I. I. (2004). Enterprise risk management. Integrated Framework.

Cnossen, S. (1994). Administrative and Compliance Costs of the VAT: A Review of the Evidence. Erasmus University Rotterdam.

Das, S. (2018). Analysis of cash flow ratios: A study on CMC. Accounting, 4(1), 41-52.

Eichfelder, S., \& Schorn, M. (2008). Tax compliance costs and its determinants: Evidence from German businesses. Institute of Accounting and Tax Management.

Eichfelder, S., \& Schorn, M. (2012). Tax compliance costs: A business-administration perspective. FinanzArchiv: Public Finance Analysis, 68(2), 191-230.

Garg, R. (2017). A systematic review of COTS evaluation and selection approaches. Accounting, 3(4), 227-236.

Hanefah, M., Ariff, M., \& Kasipillai, J. (2002). Compliance costs of small and medium enterprises. Journal of Australian Taxation, 4, 73.

Hansford, A., Hasseldine, J., \& Howorth, C. (2003). Factors affecting the costs of UK VAT compliance for small and medium-sized enterprises. Environment and Planning C: Government and Policy, 21(4), 479-492. 
Hansford, A., \& Hasseldine, J. (2012). Tax compliance costs for small and medium sized enterprises: the case of the UK.

Ibrahim, I., \& Pope, J. (2011). The viability of a pre-filled income tax return system for Malaysia. Journal of Contemporary Issues in Business and Government, 17(2), 85-102.

Kasipillai, J. (2007). A comprehensive guide to Malaysian taxation under self assessment system.

Labodová, A. (2004). Implementing integrated management systems using a risk analysis based approach. Journal of Cleaner Production, 12(6), 571-580.

Majengo, W.K. (2014). Tax Policy And Strategy Formulation.

McGregor-Lowndes, M., \& Ryan, C. (2009). Reducing the compliance burden of non-profit organisations: Cutting red tape. Australian Journal of Public Administration, 68(1), 21-38.

Reekmans, C., \& Simoens, G. (2010). How high are the tax compliance costs for Belgian SMEs. Unpublished Masters Dissertation. Ghent: Ghent University.

Smulders, S., \& Stiglingh, M. (2008). Annual tax compliance costs for small businesses: a survey of tax practitioners in South Africa. South African Journal of Economic and Management Sciences, 11(3), 354-371.

Slemrod, J. B., \& Venkatesh, V. (2002). The income tax compliance cost of large and mid-size businesses.

Schoonjans, B., Van Cauwenberge, P., Reekmans, C., \& Simoens, G. (2011). A survey of tax compliance costs of Flemish SMEs: magnitude and determinants. Environment and Planning C: Government and Policy, 29(4), 605-621.

Sapiei, N. S., \& Abdullah, M. (2014). Sources of Tax Compliance Costs for Malaysian Corporate Taxpayers. Asian Journal of Accounting Perspectives, 49-61.

Smulders, S., Stiglingh, M., Franzsen, R., \& Fletcher, L. (2017). Determinants of external tax compliance costs: Evidence from South Africa. South African Journal of Accounting Research, 31(2), 134-150.

Savitri, E. (2016). The Effect of Taxpayer Awareness, Tax Socialization, Tax Penalties, Compliance Cost at Taxpayer Compliance with Service Quality as Mediating Variable. Procedia-Social and Behavioral Sciences, 219, 682-687.

Tran-Nam, B., \& Glover, J. (2002). Tax reform in Australia: Impacts of tax compliance costs on small business. Journal of Australian Taxation, 5, 338.

Verwaal, E., \& Cnossen, S. (2002). Europe's new border taxes. JCMS: Journal of Common Market Studies, 40(2), 309-330.

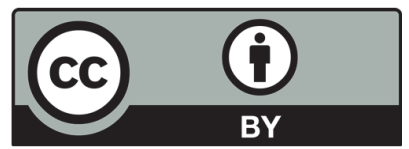

(C) 2018 by the authors; licensee Growing Science, Canada. This is an open access article distributed under the terms and conditions of the Creative Commons Attribution (CC-BY) license (http://creativecommons.org/licenses/by/4.0/). 